\title{
Some Properties of Eastern Red Cedar (Juniperus Virginiana L.) Partialeboard Panels Made Using Modified Starch as Binder
}

\section{Svojstva iverice izrađene od drva crvenog cedra i modificiranog škroba kao veziva}

\author{
Original scientific paper • Izvorni znanstveni rad \\ Received-prispjelo: 13. 9. 2019. \\ Accepted-prihvaćeno: 15. 7. 2020. \\ UDK: $630 * 861.232$ \\ https://doi.org/10.5552/drvind.2020.1947
}

\author{
(C) 2020 by the author(s). \\ Licensee Faculty of Forestry, University of Zagreb. \\ This article is an open access article distributed \\ under the terms and conditions of the \\ Creative Commons Attribution (CC BY 4.0) license.
}

\begin{abstract}
The objective of this study was to evaluate physical and mechanical properties of experimental panels manufactured from eastern red cedar (Juniperus virginiana L.) using modified starch as binder. Modulus of elasticity (MOE), modulus of rupture (MOR), internal bond strength (IB), hardness and dimensional stability in the form of thickness swelling and water absorption in addition to surface quality of the samples were tested. Panels were manufactured at three density levels, which are $0.60 \mathrm{~g} / \mathrm{cm}^{3}, 0.70 \mathrm{~g} / \mathrm{cm}^{3}$ and $0.80 \mathrm{~g} / \mathrm{cm}^{3}$. The highest MOE, MOR and IB values for the samples having $0.80 \mathrm{~g} / \mathrm{cm}^{3}$ density were determined as 2207.16 MPa, 15.17 MPa and 0.87 MPa, respectively. Thickness swelling values of the samples soaked in water for $2 \mathrm{~h}$ ranged from $15.38 \%$ to $23.23 \%$. Micrographs taken on the samples using scanning electron microscope revealed that starch was uniformly distributed within the particles. Based on the findings in this study, it appears that eastern red cedar would have a potential as a raw material to manufacture particleboard panel using modified starch as green adhesive with accepted physical and mechanical properties.
\end{abstract}

Keywords: particleboard; green adhesive; starch; mechanical properties; physical properties

SAŽETAK • Cilj istraživanja bio je odrediti fizička i mehanička svojstva eksperimentalnih ploča proizvedenih od drva crvenog cedra (Juniperus virginiana L.) uz upotrebu modificiranog škroba kao veziva. U eksperimentu su na osnovi debljinskog bubrenja i upijanja vode ispitivani modul elastičnosti (MOE), modul loma (MOR), međuslojna čvrstoća (IB), tvrdoća i dimenzijska stabilnost, kao i kvaliteta površine uzoraka. Ploče su proizvedene u tri gustoće:

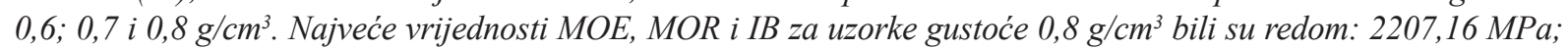
15,7 MPa i 0,87 MPa. Vrijednosti debljinskog bubrenja uzoraka potapanih u vodi tijekom dva sata kretale su se u rasponu od 15,38 do 23,23\%. Mikrografije snimljene na uzorcima elektronskim pretražnim mikroskopom otkrile su da je škrob ravnomjerno raspoređen unutar iverja. Na temelju rezultata ovoga istraživanja, čini se da bi drvo crvenog cedra moglo biti potencijalna sirovina za proizvodnju iverica, uz uporabu modificiranog škroba kao ekološki prihvatljivog ljepila poželjnih fizičkih i mehaničkih svojstava.

Ključne riječi: iverica; ekološki prihvatljivo ljepilo; škrob; mehanička svojstva; fizička svojstva

\footnotetext{
Authors is researcher at Kirikkale Universitesi, Kirikkale, Turkey.

2 Author is researcher at Oklahoma State University, Department of Natural Resource Ecology and Management, Oklahoma, USA.
} 


\section{INTRODUCTION}

\section{UVOD}

Wood composite panels, such as particleboard, fiberboard, and oriented strand board, are widely used for both non-structural and structural applications. Particleboard is the oldest composite panel that still has a significant market share among the other types of panels. It is mainly used for furniture, cabinet and paneling manufacture in addition to substrate for thin overlays. Most of the time, small diameter logs of softwood and hardwood species, such as pine, aspen or waste from sawmills, are used as raw material for particleboard production. Formaldehyde based adhesives, including urea formaldehyde (UF), are the most used binder in particleboard manufacture due to their low cost and excellent adhesion performance. On the other hand, interior panels, namely particleboard and fiberboard with different density, are two prime products manufactured using UF, which have been on commercial market not only in the USA but also in Europe and Asia for decades. Although UF is the most used adhesive in composite panel production, having formaldehyde in its chemical structure creates important environmental and health issues, since formaldehyde is a possible cancerogenic substance.

Most effective way to omit formaldehyde emission from wood based panels is to use formaldehydefree or bio-based resins like starch-based resins. Starch is a carbohydrate material that consists of amylase and amylopectin, which could be differentiated by its chemical structure. The linear a- $(1 \rightarrow 4)$ linked glucan is called amylase, while an a- $(1 \rightarrow 4)$ linked glucan with $4.2-5.9 \%$ a- $(1 \rightarrow 6)$ branch linkages is amylopectin (Robyt, 2008; Amini et al., 2013). It can be obtained from various plant materials, such as corn, potato, rice, wheat, sago and many others, and it is widely available throughout the world as it is commonly used in food industry. Therefore, modification of starch was well documented by many researchers (Verwimp et al., 2004; Amini et al., 2013; Yu et al., 2013).

Chemical modification allows starches to be green adhesive solvent in furniture industry. Esterification, etherification, and cross-linking are well-known reactions for chemical modification of starch. These includ succinylation (Phillips et al., 2000), maleination (Chong et al., 2001), and acetylation (Phillips et al., 1999), which can enhance starch functional value and broaden its range of physico-chemical properties. Chemical modification of starch is commonly carried out in aqueous media, water being considered a green, environmentally friendly solvent (Bodîrlău et. al., 2014; H’ng et al., 2011).

The chemical modification reactions determine the cross-linking process, which is a common approach to improve the performance of starch for various applications (Huang et al., 2007; Wang et al., 2010). Determination of the modification degree (Phillips et al., 2000) and classification of chemically modified starches using infrared spectros-copy has been described (Dolmatova et al., 1998; Dupuy et al., 1997).
Eastern red cedar (Juniperus virginiana L.) is considered an invasive species encroaching in the Great Plains and one of the predominant woody species in the United States. It is also one of widely distributed species in Oklahoma. Current area covered by Eastern red cedar in Oklahoma is estimated around 4.5 million hectares and it is projected to be more than 6.3 million hectares within next 10 years. It is claimed that the red cedar has a growing rate of 380 hectares per day resulting in a significant adverse impact on ecology (Ulker and Hiziroglu, 2017). Generally, red cedar trees are relatively low value trees due to their irregular growth pattern; therefore, lumber manufacture from eastern red cedar is limited to trees with larger diameter. However, red cedar trees can still be used to manufacture different products like indoor and outdoor furniture units, paneling, novelty items, mulch and even composite panels. Different types of experimental particleboard, waferboard and sandwich type of panels, were produced in previous studies (McKinley and Blair, 2008; Reddin and Krementz, 2016; Yang et al., 2016; Bragg and Hulbert, 1976; Hiziroglu, 2012; Ulker and Burdurlu, 2016; Hiziroglu et al., 2002).

It was determined that both physical and mechanical properties of red cedar particleboard panel products were comparable to those manufactured from different species at commercial scale. Currently, there is very limited or no information on properties of particleboard made from eastern red cedar bonded with modified starch. Therefore, the main objective of this work was to determine the basic properties of the particleboard made from eastern red cedar bonded with green adhesive.

\section{MATERIALS AND METHODS}

\section{MATERIJALI I METODE}

Commercially produced eastern red cedar (Juniperus virginiana L.) particles supplied by a local producer in Oklahoma were used to produce experimental panels. Dried particles having a moisture content of 3 $\%$ were classified into fine and coarse sizes on a 0.841 $\mathrm{mm}$ (20 mesh) and $0.250 \mathrm{~mm}$ (60 mesh) screen, respectively. Coarse particles were used for the core layer of the three-layer particleboard, while the fine particles were used for the surface layers of the panel.

Glutardialdehyde (GDA), which was used as starch modifier in our study, is a colorless oily liquid organic compound having the formula $\mathrm{CH}_{2}\left(\mathrm{CH}_{2} \mathrm{CHO}\right)_{2}$. GDA is widely used as a disinfector agent for medical equipment. Glutardialdehyde (GDA) acts as a curing agent and plays an important role in uniform distribution of starch on the particles. GDA used for modification of corn starch, was mixed and stirred at room temperature. Corn starch powder was dissolved in distilled water $(100 \mathrm{ml})$ at a temperature of $30^{\circ} \mathrm{C}$ before it was mixed with GDA. The share of the added GDA was 25 $\%$ based on volume. No wax or any other additives were used in the panel production.

The ratio of the surface layer mass to the total mass of a panel, known as the shelling ratio, was 0.25 for all sample panels. Shelling ratio was determined 


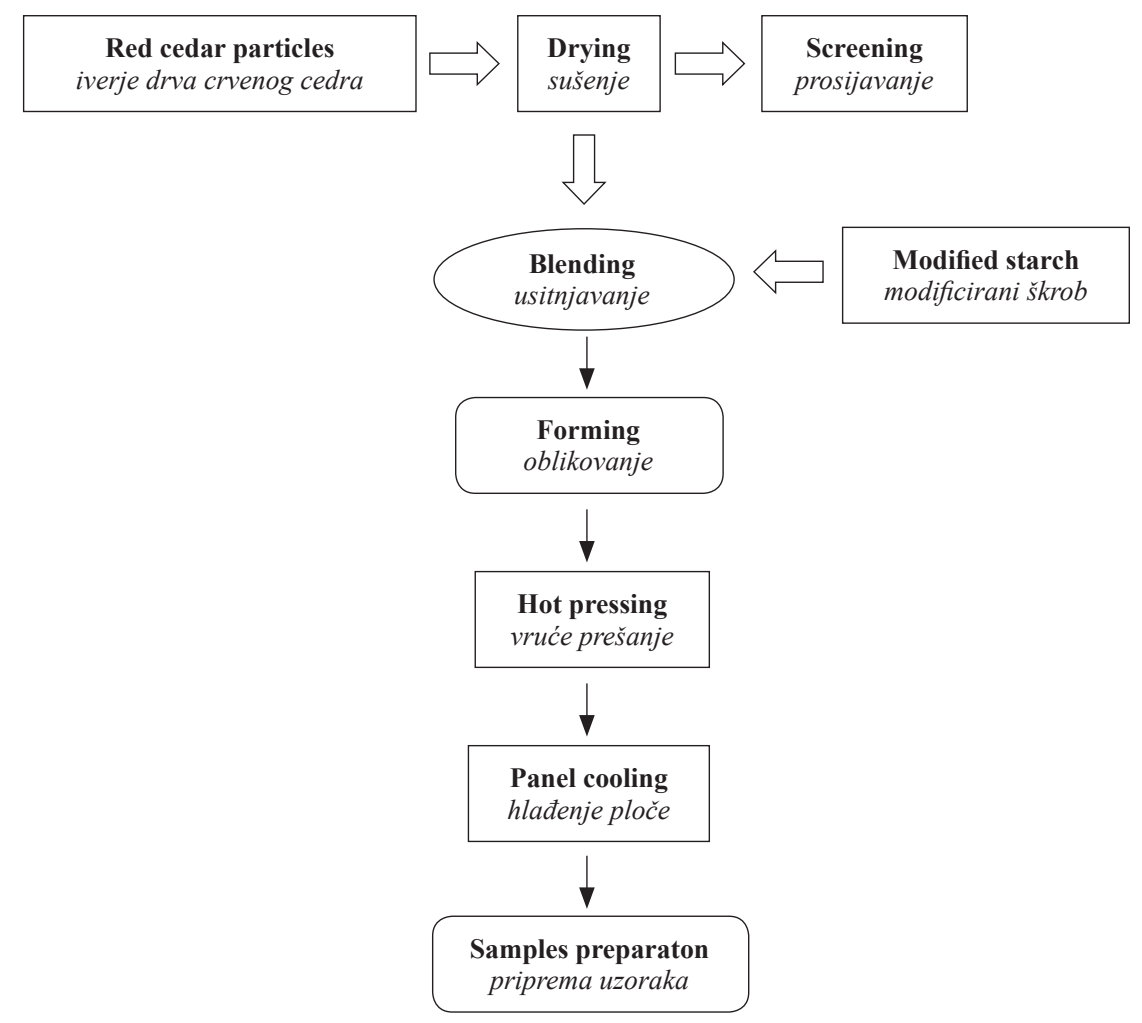

Figure 1 Panel manufacturing process

Slika 1. Proces proizvodnje ploče

using precision scales. Hand formed mats were pressed in a computer-controlled press (Erie Mill and Press Company, Inc., $60.9 \mathrm{~cm}$ by $60.9 \mathrm{~cm} 270$-ton press) using a pressure of $5.5 \mathrm{MPa}$ at a temperature of $180{ }^{\circ} \mathrm{C}$, for 5 minutes. A total of fifteen panels were made for each of the three density levels, which were $0.60 \mathrm{~g} /$ $\mathrm{cm}^{3}, 0.70 \mathrm{~g} / \mathrm{cm}^{3}$ and $0.80 \mathrm{~g} / \mathrm{cm}^{3}$. The process of panel manufacturing is presented in Figure 1. Panels were conditioned in a climate room at $65 \%$ relative humidity and a temperature of $20^{\circ} \mathrm{C}$ for two weeks before the samples were cut for different tests based on ASTM (American Society for Testing Materials) D1037-12 (ASTM International, 2012).

The mechanical properties of the specimens were carried out on a Comten Testing System, Model 95-VD equipped with $1000 \mathrm{~kg}$ load cell. ASTM D1037-12 procedures were used to determine bending strength and internal bond strength test. The samples with the size of $50 \mathrm{~mm}$ by $300 \mathrm{~mm}$ by $12 \mathrm{~mm}$ from each panel type were tested for their bending strength properties.

Internal bond strength $(I B)$ of the panels was determined using sample $50 \mathrm{~mm}$ by $50 \mathrm{~mm}$ cross sections. Hardness of the sample panels was tested by embedding a hemisphere steel having $11.2 \mathrm{~mm}$ diameter onto surface of panels using Comten 95 Series Universal Testing machine. Surface characteristics of the samples with $50 \mathrm{~mm}$ by $300 \mathrm{~mm}$ by $12 \mathrm{~mm}$ were evaluated by employing a fine stylus profilometer Hommel T-500 unit, which has TkE model pick-up, equipped with a skid type diamond stylus having $5 \mu \mathrm{m}$ tip radius and a $90^{\circ}$ tip angle (Hiziroglu et al., 2004). The stylus traversed the surface at a constant speed of $1 \mathrm{~mm} / \mathrm{s}$ over a $15.2 \mathrm{~mm}$ tracing length and the vertical displacement of the stylus was converted into an electrical signal. Average roughness, $\left(R_{\mathrm{a}}\right)$, mean peak-to-valley height $\left(R_{\mathrm{z}}\right)$, and maximum peak height value $\left(R_{\max }\right)$ were used for the evaluation of the surface roughness of specimens.

The samples were also examined using a scanning electron microscope, FEI Quanta 600 FEG scanning electron microscope with an EVEX X-ray microanalysis system. The specimens of $5 \mathrm{~mm}$ by $10 \mathrm{~mm}$ by $6 \mathrm{~mm}$ were prepared from the panels of $0.8 \mathrm{~g} / \mathrm{cm}^{3}$ density. The images were taken with a SEM operated at 15 $\mathrm{kV}$. All the specimens were coated with thin gold layer prior to the analysis.

Thickness swelling (TS) and water absorption $(W A)$ tests were carried out by soaking specimens of $100 \mathrm{~mm}$ by $100 \mathrm{~mm}$ by $12 \mathrm{~mm}$ in distilled water for 2 and $24 \mathrm{~h}$ based on ASTM D1037-12 standard. The specimens were submerged horizontally under $25 \mathrm{~mm}$ of water maintained at a temperature of $(20 \pm 1){ }^{\circ} \mathrm{C}$. After a $2 \mathrm{~h}$ submersion, the specimens were taken out to drain for $(10 \pm 2) \mathrm{min}$, then the excessive water was removed and they were immediately weighed. Their thickness was measured at four corners at accuracy of $0.01 \mathrm{~mm}$ at each soaking period. Then the specimens were submerged for an additional period of $22 \mathrm{~h}$ and the above weighing and measuring procedures were repeated. WA and TS test were carried out to analyze the dimensional stability of panels.

Analysis of variance (ANOVA) was used to analyze the significant differences among the specimens manufactured with three different densities. The data were statistically analyzed at a confidence level of $p$ value $=0.05$ and Duncan's multiple range test was also carried out using SAS 9.4 software (SAS Institute Inc., Cary, NC) for multiple comparison. 


\section{RESULTS AND DISCUSSION}

\section{REZULTATI I RASPRAVA}

Average and standard deviation values (in parentheses) of mechanical and physical properties of the samples are presented in Table 1 .

Panel type A with the density of $0.80 \mathrm{~g} / \mathrm{cm}^{3}$ resulted in the highest MOE, MOR and IB values of 2207.16 MPa, 15.17 MPa and 0.87 MPa, respectively. These values were followed by panel type $\mathrm{B}$ and $\mathrm{C}$ as a function of their density levels. It is a well-known fact that the overall density influences most the mechanical properties of particleboards (Kelly, 1977; Ulker and Burdurlu, 2016; Ayrilmis, 2007; Cai and Ross, 2010). Both bending and $I B$ strength values of experimental samples increased with increasing the density levels of the panels. Overall findings in this work also confirmed such trend. In a previous work, carried out using eastern red cedar as raw material and a combination of urea formaldehyde and modified starch as binder in particleboard manufacture, $M O E$ and $M O R$ values were 2344.32 MPa and 12.14 MPa, respectively (Chotikhun and Hiziroglu, 2017).

Experimental panels with the density of $0.80 \mathrm{~g} /$ $\mathrm{cm}^{3}$ of the same type of raw material mixed with $7 \%$ urea formaldehyde resulted in 2.31 MPa for the above values. It seems that using only modified starch as a binder in the panels adversely influences their bending characteristics. Table 2 displays statistical analysis of $M O E, M O R$, and $I B$ values of the samples.
Based on ANOVA, it was found that significant difference existed among the properties of the samples as a function of their density levels. Table 3 gives the means for groups of homogeneous subsets.

As mentioned above, mechanical properties of the panels with the density of $0.80 \mathrm{~g} / \mathrm{cm}^{3}$ and $0.70 \mathrm{~g} /$ $\mathrm{cm}^{3}$ were found satisfactory based on TS-EN 312 (Particleboards Specifications) standard, while the particleboard with the density of $0.60 \mathrm{~g} / \mathrm{cm}^{3}$ does not meet the requirements of TS-EN 312 standard.

Dimensional stability in terms of thickness swelling and water absorption of the samples resulted in relatively low values. Thickness swelling of the samples ranged from $15.38 \%$ to $31.40 \%$ as a result of 2 and $24 \mathrm{~h}$ water soaking. The lowest thickness swelling of $15.38 \%$ was determined for the panels with the density of $0.8 \mathrm{~g} / \mathrm{cm}^{3}$ exposed to $2 \mathrm{~h}$ water soaking. The highest thickness swelling of $31.40 \%$ was found for the panels with the density of $0.60 \mathrm{~g} / \mathrm{cm}^{3}$ at $24 \mathrm{~h}$ water soaking. In a previous work, thickness swelling values of particleboard panels, made using a combination of starch and $2 \%$ UF, ranged from $26 \%$ to $37 \%$ (Chotikhun and Hiziroglu, 2017; Garay, 2012). Water absorption values of the samples ranged from $116.80 \%$ to $164.30 \%$ as a function of 2 and $24 \mathrm{~h}$ water soaking. Past studies that used different types of raw materials and starch as a binder also found comparable thickness swelling and water absorption values as those found in this study (Chotikhun and Hiziroglu, 2017). It is a known fact that any kind of starch, including corn

Table 1 Average values of mechanical and physical properties of samples (Standard deviation given in parentheses)

Tablica 1. Srednje vrijednosti mehaničkih i fizičkih svojstava uzoraka (u zagradama su standardne devijacije)

\begin{tabular}{|c|c|c|c|c|c|c|c|c|c|c|c|c|}
\hline \multirow{3}{*}{$\begin{array}{l}\text { Panel } \\
\text { type } \\
\text { Vrsta } \\
\text { ploče }\end{array}$} & \multirow{3}{*}{$\begin{array}{c}\text { Density } \\
\text { g/cm } \\
\text { Gustoća } \\
\mathrm{g} / \mathrm{cm}^{3}\end{array}$} & \multicolumn{2}{|c|}{$\begin{array}{l}\text { Bending, MPa } \\
\text { Savijanje, } \mathrm{MPa}\end{array}$} & \multirow{3}{*}{$\begin{array}{c}\text { IB } \\
\text { strength, } \\
\text { N/mm } \\
\text { Međuslojna } \\
\text { čvrstoća, } \\
\mathrm{N} / \mathrm{mm}^{2}\end{array}$} & \multirow{3}{*}{$\begin{array}{c}\text { Janka } \\
\text { hardness } \\
\text { N/mm² } \\
\text { Tvrdoća } \\
\text { po Janki, } \\
\mathrm{N} / \mathrm{mm}^{2}\end{array}$} & \multicolumn{4}{|c|}{$\begin{array}{l}\text { Dimensional stability } \\
\text { Dimenzijska stabilnost }\end{array}$} & \multirow{2}{*}{\multicolumn{3}{|c|}{$\begin{array}{l}\text { Surface roughness, } \mu \mathrm{m} \\
\text { Hrapavost površine, } \mu \mathrm{m}\end{array}$}} \\
\hline & & \multirow[t]{2}{*}{$\begin{array}{c}M O E \\
\mathrm{~N} / \mathbf{m m}^{2}\end{array}$} & \multirow[t]{2}{*}{$\begin{array}{c}\text { MOR } \\
\mathbf{N} / \mathbf{m m}^{2}\end{array}$} & & & \multicolumn{2}{|c|}{$\begin{array}{c}\text { Thickness } \\
\text { swelling, \% } \\
\text { Debljinsko } \\
\text { bubrenje, \% }\end{array}$} & \multicolumn{2}{|c|}{$\begin{array}{c}\text { Water } \\
\text { absorption, \% } \\
\text { Upijanje vode, } \\
\%\end{array}$} & & & \\
\hline & & & & & & 2-h & 24-h & $2-\mathrm{h}$ & 24-h & $R_{\mathrm{a}}$ & $R_{\mathrm{z}}$ & $R_{\max }$ \\
\hline A & 0.80 & $\begin{array}{l}2207.16 \\
(23.32)\end{array}$ & $\begin{array}{c}15.17 \\
(22.28)\end{array}$ & $\begin{array}{c}0.87 \\
(15.77)\end{array}$ & $\begin{array}{c}6.00 \\
(15.01)\end{array}$ & $\begin{array}{c}15.38 \\
(16.40)\end{array}$ & \begin{tabular}{|c|}
18.32 \\
$(19.57)$ \\
\end{tabular} & $\begin{array}{l}132.17 \\
(2.35)\end{array}$ & $\begin{array}{l}164.30 \\
(3.84)\end{array}$ & $\begin{array}{l}11.74 \\
(3.03)\end{array}$ & $\begin{array}{l}28.49 \\
(8.88)\end{array}$ & $\begin{array}{c}43.32 \\
(13.09)\end{array}$ \\
\hline B & 0.70 & $\begin{array}{l}1732.31 \\
(15.05)\end{array}$ & \begin{tabular}{|c|}
13.05 \\
$(14.29)$ \\
\end{tabular} & $\begin{array}{c}0.78 \\
(25.94)\end{array}$ & $\begin{array}{c}5.70 \\
(16.70)\end{array}$ & $\begin{array}{c}15.45 \\
(15.23)\end{array}$ & \begin{tabular}{|c|}
23.10 \\
$(19.15)$
\end{tabular} & $\begin{array}{l}123.90 \\
(1.91)\end{array}$ & $\begin{array}{l}160.60 \\
(2.94)\end{array}$ & $\begin{array}{l}14.30 \\
(2.24)\end{array}$ & $\begin{array}{c}30.50 \\
(10.47)\end{array}$ & \begin{tabular}{|c|}
48.17 \\
$(10.38)$ \\
\end{tabular} \\
\hline $\mathrm{C}$ & 0.60 & $\begin{array}{l}1136,23 \\
(10.92)\end{array}$ & $\begin{array}{c}6.18 \\
(11.18)\end{array}$ & $\begin{array}{c}0.45 \\
(12.53)\end{array}$ & $\begin{array}{c}5.46 \\
(13.55)\end{array}$ & $\begin{array}{c}23.23 \\
(17.27)\end{array}$ & \begin{tabular}{|c|}
31.40 \\
$(19.39)$
\end{tabular} & $\begin{array}{c}116.80 \\
(1.65)\end{array}$ & $\begin{array}{c}153.70 \\
(2.19)\end{array}$ & $\begin{array}{l}18.07 \\
(3.53)\end{array}$ & $\begin{array}{c}37.56 \\
(10.70)\end{array}$ & $\begin{array}{c}60.54 \\
(17.46)\end{array}$ \\
\hline
\end{tabular}

Table 2 Statistical analysis of $M O E, M O R$, and $I B$ values of the samples based on ANOVA

Tablica 2. Statistička analiza ANOVA za vrijednosti $M O E, M O R$ i $I B$ uzoraka

\begin{tabular}{|c|l|c|c|c|c|c|}
\hline \multicolumn{2}{|c|}{} & $\begin{array}{c}\text { Sum of Squares } \\
\text { Zbroj kvadrata }\end{array}$ & $d f$ & $\begin{array}{c}\text { Mean Square } \\
\text { Kvadrat srednje } \\
\text { vrijednosti }\end{array}$ & F & $\begin{array}{c}\text { Significance } \\
\text { Značajnost }\end{array}$ \\
\hline \multirow{3}{*}{ MOE } & Between Groups / između skupina & 438978.156 & 2 & 219489.07 & 665.85 & .000 \\
\cline { 2 - 7 } & Within Groups / unutar skupina & 8900.211 & 27 & 329.63 & & \\
\cline { 2 - 7 } & Total / ukupno & 447878.367 & 29 & & & \\
\hline \multirow{3}{*}{ MOR } & Between Groups / između skupina & 9560381.267 & 2 & 4780190.63 & 15646.91 & .000 \\
\cline { 2 - 8 } & Within Groups / unutar skupina & 8248.600 & 27 & 305.50 & & \\
\cline { 2 - 8 } & Total / ukupno & 9568629.867 & 29 & & & .000 \\
\hline \multirow{3}{*}{$I B$} & Between Groups / između skupina & 21475.616 & 2 & 10737.80 & 26.87 & \\
\cline { 2 - 8 } & Within Groups / unutar skupina & 10789.387 & 27 & 399.60 & & \\
\cline { 2 - 7 } & Total / ukupno & 32265.003 & 29 & & & \\
\hline
\end{tabular}


....... Ulker, Hiziroglu: Some Properties of Eastern Red Cedar (Juniperus Virginiana L.)...

Table 3 Means for groups of homogeneous subsets

Tablica 3. Srednje vrijednosti za grupe homogenih podskupova

\begin{tabular}{|c|c|c|c|c|c|}
\hline \multirow{2}{*}{$\begin{array}{l}\text { Mechanical properties } \\
\text { Mehanička svojstva }\end{array}$} & \multirow{2}{*}{$\begin{array}{l}\text { Panel type } \\
\text { Vrsta ploče }\end{array}$} & \multirow{2}{*}{$\begin{array}{c}\text { Number of samples } \\
\text { Broj uzoraka }\end{array}$} & \multicolumn{3}{|c|}{$\begin{array}{l}\text { Subset for alpha } \mathbf{0 . 0 5} \\
\text { Podskup za alfa } 0,05\end{array}$} \\
\hline & & & 1 & 2 & 3 \\
\hline \multirow{3}{*}{$M O E, \mathrm{MPa}$} & $\mathrm{A}\left(0.80 \mathrm{~g} / \mathrm{cm}^{3}\right)$ & 10 & 2207.16 & & \\
\hline & $\mathrm{B}\left(0.70 \mathrm{~g} / \mathrm{cm}^{3}\right)$ & 10 & & 1732.31 & \\
\hline & $\mathrm{C}\left(0.60 \mathrm{~g} / \mathrm{cm}^{3}\right)$ & 10 & & & 1136.23 \\
\hline \multirow{3}{*}{$M O R, \mathrm{MPa}$} & $\mathrm{A}\left(0.80 \mathrm{~g} / \mathrm{cm}^{3}\right)$ & 10 & 15.17 & & \\
\hline & $\mathrm{B}\left(0.70 \mathrm{~g} / \mathrm{cm}^{3}\right)$ & 10 & & 13.05 & \\
\hline & $\mathrm{C}\left(0.60 \mathrm{~g} / \mathrm{cm}^{3}\right)$ & 10 & & & 6.18 \\
\hline \multirow{3}{*}{$I B, \mathrm{MPa}$} & $\mathrm{A}\left(0.80 \mathrm{~g} / \mathrm{cm}^{3}\right)$ & 10 & 0.87 & & \\
\hline & $\mathrm{B}\left(0.70 \mathrm{~g} / \mathrm{cm}^{3}\right)$ & 10 & 0.78 & & \\
\hline & $\mathrm{C}\left(0.60 \mathrm{~g} / \mathrm{cm}^{3}\right)$ & 10 & & 0.45 & \\
\hline
\end{tabular}

starch used in this work, is hygroscopic material influencing adversely overall dimensional stability of the panels. Additionally, not using any wax in the panels manufactured would be considered as one of the reasons for slightly high thickness swelling and water absorption characteristics of the samples. Although the samples had somehow high dimensional instability, none of them disintegrated or crumbled as a result of water soaking test.

Since most of the particleboards are used as substrate for thin overlays, their surface quality in terms of roughness plays an important role during their service life. The average roughness $\left(R_{\mathrm{a}}\right)$ value of $11.74 \mu \mathrm{m}$ was determined for the samples with $0.80 \mathrm{~g} / \mathrm{cm}^{3}$. Boards with lower density had rougher surface, which can be related to their less densified surface. A typical commercially manufactured particleboard could have $R_{\mathrm{a}}$ values ranging from $3.80 \mu \mathrm{m}$ to $5.90 \mu \mathrm{m}$ (Hiziroglu, 1996; Chotikhun and Hiziroglu, 2017). Also most of the commercially manufactured particleboard panels are sanded with up to 180 grit sand paper, which gives a very uniform smooth surface. None of the samples was sanded in this work. If the surface of the experimental panels had been sanded, surely $R_{\mathrm{a}}$ values, along with other two roughness parametres, would have been much lower.

Amini et al. (2013) worked on properties of particleboard made from rubberwood using modified starch as binder, in their publication. Figure 2.1 shows, with black arrows, SEM cross sectional view of particleboard made using glutardialdehyde modified corn starch as a binder at 500 magnification with the presence of modified corn starch granules. In our study, we also had SEM cross sectional view of particleboard made using glutardialdehyde modified corn starch as a binder at 1500 magnification with the presence of modified corn starch granules. Uniform distiribution of starch throughout the particle could be considered as one of the responsible parameters. As can be seen in Figure 2.2, starch was distrubuted quite uniformly among the particles even though manual mixture was used during the panel manufacture.

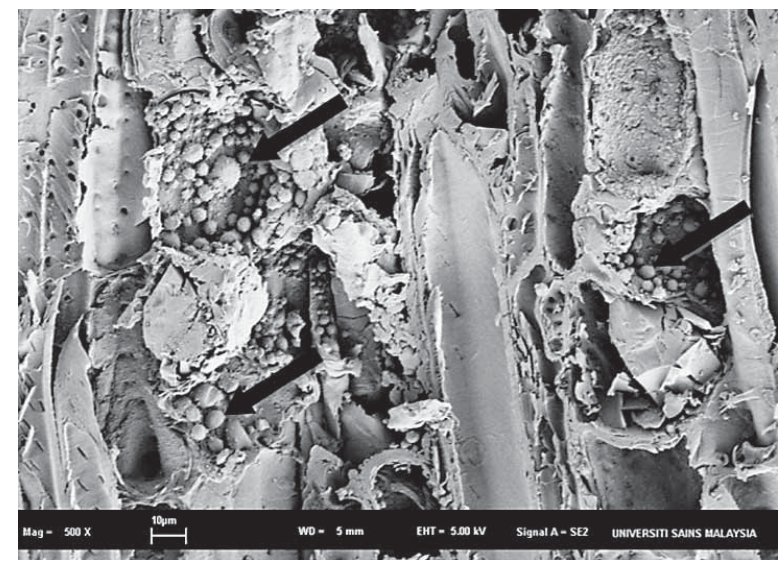

a)

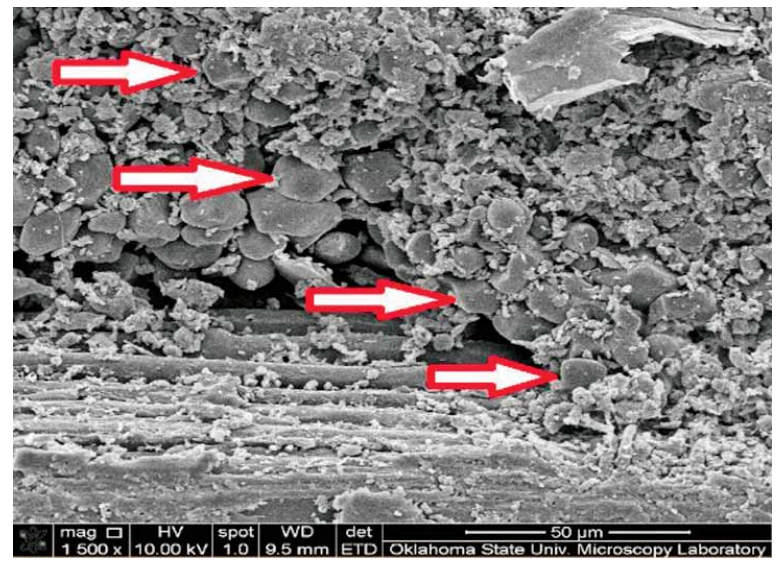

b)

Figure 2 SEM cross sectional view of particleboard made using GDA modified corn starch as a binder: a) SEM cross sectional view of particleboard made using GDA modified corn starch as a binder at 500 magnification with the presence of modified corn starch granules shown with black arrows (Amini et al., 2013); b) SEM cross sectional view of particleboard made using GDA modified corn starch as a binder at 1500 magnification with the presence of modified corn starch granules shown with white-red colored arrows

Slika 2. SEM presjeci iverice proizvedene upotrebom GDA modificiranoga kukuruznog škroba kao veziva: a) SEM presjek iverice proizvedene uz dodatak GDA modificiranoga kukuruznog škroba kao veziva pri povećanju od 500 puta, s vidljivim granulama kukuruznog škroba označenima crnim strelicama (Amini et al., 2013.), b) SEM presjek iverice proizvedene primjenom GDA modificiranoga kukuruznog škroba kao veziva pri povećanju od 1500 puta, s vidljivim granulama kukuruznog škroba označenima bijelo-crvenim strelicama 
It is a known fact that overall strength properties of particleboard is a function of glueline between the particles. As can be observed from the micrographs taken on SEM, starch was distributed relatively uniformly, which resulted in enhanced bonding among the particles. Such finding was also reflected in overall properties tested in this work.

\section{CONCLUSIONS}

4. ZAKLJUČAK

Fundamental mechanical and physical properties of the experimental panels made in this work showed satisfactory values with the exception, to a certain extent, of dimesional stability. It seems that $100 \%$ modified starch with GDA would have a potentional to be used as green adhesive in the manufacture of particleboard. This approach, combined with an invasive species, such as eastern red cedar, would result in green panels that would be particularly attractive in terms of sustainability and environmental friendliness.

\section{Acknowledgements - Zahvala}

The authors would like to acknowledge the support of the Scientific and Technological Research Council of Turkey Agency (TUBITAK) in the framework of the International Post-Doctoral Research Scholarship Program- 2219.

\section{REFERENCES}

5. LITERATURA

1. Amini, M. H.; Hashim, M. R.; Hiziroglu, S.; Sulaiman, N. S.; Sulaiman, O., 2013: Properties of particleboard made from rubberwood using modified starch as binder. Composites: Part B, 50: 259-264.

https://doi.org/10.1016/j.compositesb.2013.02.020.

2. Ayrilmis, N., 2007: Effect of panel density on dimensional stability of medium and high density fiberboards. Journal of Materials Science, 42 (20): 8551-8557.

3. Bragg, T. B; Hulbert, L. C., 1976: Woody plant invasion of unburned Kansas bluestem prairie. Journal of Range Management 29: 19-24. https://doi.org/10.2307/3897682.

4. Bodîrlău, R.; Teacă, C. A.; Spiridon, I., 2014: Green composites comprising thermoplastic corn starch and various cellulose-based fillers. BioResources, 9 (1): 39 53. https://doi.org/10.15376/biores.9.1.39-53.

5. Cai, Z.; Ross, R. J., 2010: Mechanical properties of wood-based composite materials. Wood handbook: wood as an engineering material: chapter 12. Centennial ed. General technical report FPL; GTR-190. Madison, WI: US Dept. of Agriculture, Forest Service, Forest Products Laboratory, 190: 12.1-12.12.

6. Chong, C. K.; Xing, J.; Phillips, D. L.; Corke, H., 2001: Development of NMR and Raman spectroscopic methods for the determination of the degree of substitution of maleate in modified starches. J. Agric. Food Chem. 14 (4): 541-550. https://doi.org/10.1021/jf0102160.

7. Chotikhun, A.; Hiziroglu, S., 2017: Some properties of composite panels manufactured from Eastern red cedar (Juniperus virginiana L.) using modified starch as a green binder. Journal of Natural Fibers 49 (6): 27022708. https://doi.org/10.1080/15440478.2016.1240642.

8. Dolmatova, L.; Ruckebusch, C.; Dupuy, N.; Huvenne, J.P.; Legrand, P., 1998: Identification of modified starches using infrared spectroscopy and artificial neural network processing. Applied Spectroscopy, 52 (3): 329-338. https://doi.org/10.1366/0003702981943752.

9. Dupuy, N.; Wojciechowski, C.; Ta, C. D., Huvenne, J. P.; Legrand, P., 1997: Mid-infrared spectroscopy and chemometrics in corn starch classification. Journal of Molecular Structure, 410: 551-554. https://doi.org/10.1016/ S0022-2860(96)09517-8.

10. Eastin, I.; Le Roy, M.; Maplesden, F.; Novoselov, I., 2016: Wood-based panels, Chapter 7, UNECE/FAO Forest Products Annual Market Review, 69-82.

11. Garay, R. M., 2012: Lab testing for P3 moisture resistant overlaid particleboards made from wood residues. BioResources, 7 (3): 3093-3103.

12. H’ng, P. S.; Lee, S. H.; Loh, Y. W.; Lum, W. C.; Tan, B. H., 2011: Production of low formaldehyde emission particleboard by using new formulated formaldehyde-based resin. Asian Journal of Scientific Research, 4: 264-270. https://doi.org/10.3923/ajsr.2011.264.270.

13. Hiziroglu, S., 1996: Surface roughness analysis of wood composites: a stylus method. Forest Products Journal, 46 (7/8): 67-72.

14. Hiziroglu, S., 2012: Some properties of sandwich type composite panels manufactured from Eastern red cedar. Composites: Part B, 43: 3288-3292.

https://doi.org/10.1016/j.compositesb.2012.02.009.

15. Hiziroglu, S.; Holcomb, R. B.; Wu, Q., 2002: Manufacturing particleboard from Eastern red cedar. Forest Products Journal, 52: 72-75.

16. Hiziroglu, S.; Jarusombuti, S.; Fueangvivat, V., 2004: Surface characteristics of wood composites manufactured in Thailand. Building and Environment, 39: 13591364. https://doi.org/10.1016/j.buildenv.2004.02.004.

17. Hiziroglu, S.; Holcomb, R., 2005: Some of the properties of three-layer particleboard made from Eastern red cedar. Building and Environment, 40: 719-723. https://doi.org/10.1016/j.buildeny.2004.05.016.

18. Huang, J. R.; Schols, H. A.; Klaver, R.; Jin, Z. Y.; Voragen, A. G. J., 2007: Acetyl substitution patterns of amylose and amylopectin populations in cowpea starch modified with acetic anhydride and vinyl acetate. Carbohydrate Polymers, 67: 542-550. https://doi.org/10.1016/j.carbpol.2006.06.027.

19. Kelly, M. W., 1977: Critical literature review of relationships between processing parameters and physical properties of particleboard (vol. 10). US Department of Agriculture, Forest Service, Forest Products Laboratory.

20. McKinley, D.; Blair, J., 2008: Woody plant encroachment by Juniperus virginiana in a mesic native grassland promotes rapid carbon and nitrogen accrual. Ecosystems, 11: 454-468. https://doi.org/10.1007/s10021-008-9133-4.

21. Moubarik, A.; Mansouri, H. R.; Pizzi, A.; Allal, A.; Charrier, F.; Badia, M. A.; Charrier, B., 2013: Evaluation of mechanical, physical properties of industrial particleboard bonded with a corn flour-urea formaldehyde adhesive. Composites, Part B, 44: 48-51. https://doi.org/10.1016/j.compositesb.2012.07.041.

22. Phillips, D. L.; Lui, H., Pan, D.; Corke, H., 1999: General application of Raman spectroscopy for the determination of acetylation in modified starches. Cereal Chemistry, 76: 339-443. https://doi.org/10.1094/CCHEM.1999.76.3.439.

23. Phillips, D. L.; Xing, J.; Chong, C. K.; Lui, H.; Corke, H., 2000: Determination of the degree of succinylation in diverse modified starches by Raman spectroscopy. Journal of Agricultural and Food Chemistry, 48: 5105-5108. https://doi.org/10.1021/jf9907790. 
24. Reddin, C. J.; Krementz, D. C., 2016: Small mammal communities in Eastern red cedar forest. The American Midland Naturalist, 175(1): 113-119. https://doi.org/10.1674/amid-175-01-113-119.1.

25. Robyt, J. F., 2008: Starch: structure, properties, chemistry and enzymology. In: FraserReid OB, Tatsuta K., Thiem J., (eds). Glycoscience chemistry and chemical biology. Berlin (Heidelberg, New York): Springer-Verlag; pp. 2866. http://doi.org/10.1007/978-3-540-30429-6_35.

26. Ulker, O.; Hiziroglu, S., 2017: Some properties of densified eastern red cedar as function of heat and pressure. Materials, 10(11): 1275-1285. https://doi.org/10.3390/ma10111275.

27. Verwimp, T.; Vandeputte, G. E.; Marrant, K.; Delcour, J. A., 2004: Isolation and characterisation of rye starch. Journal of Cereal Science, 39 (1): 85-90. http://doi.org/10.1016/S0733-5210(03)00068-7.

28. Wang, L. F.; Pan, S. Y.; Hu, H.; Miao, W. H.; Xu, X. Y., 2010: Synthesis and properties of carboxymethyl kudzu root starch. Carbohydrate Polymers, 80: 174-179. https:// doi.org/10.1016/j.carbpol.2009.11.008.

29. Yang, Z.; Kumar, A.; Huhnke, R. L.; Buser, M.; Capared, S., 2016: Pyrolysis of eastern Red cedar distribution and characteristics of fast and slow pyrolysis products. Fuel, 166: 157-165. https://doi.org/10.1016/j.fuel.2015.10.101.

30. Yu, L.; Liu, X.; Petinakis, E.; Dean, K.; Bateman, S., 2013: Starch Based Blends Composites and Nanocomposites, Chapter 4. Advances in Natural Polymers: Composites and Nanocomposites. Springer, Heidelberg, New York. pp. 121-154. https://doi.org/10.1007/978-3-64220940-6 4.

31. ***ASTM International 2012: ASTM D1037-12 Standard Test Methods for Evaluating Properties of WoodBase Fiber and Particle Panel Materials. https://doi. org/10.1520/D1037-12.

\section{Corresponding address:}

\section{ONUR ULKER}

Kirikkale Universitesi

Kirikkale, TURKEY

e-mail: onur79o@hotmail.com 